\title{
How Chromium-Resistant Bacteria Can Improve Corn Growth in Chromium-Contaminated Growing Medium
}

\author{
Hadia-e-Fatima, Ambreen Ahmed* \\ Department of Botany, University of the Punjab, Quaid-e-Azam Campus, \\ Lahore 54590, Pakistan
}

Received: 16 February 2016

Accepted: 21 May 2016

\begin{abstract}
Chromium is a heavy metal found in various oxidation states $\left(\mathrm{Cr}^{3+}\right.$ to $\left.\mathrm{Cr}^{6+}\right)$. It is a highly toxic metal widely used in a number of industries and is generally found to have a carcinogenic impact on living organisms. Although there are chemical and biological approaches for reducing chromium toxicity in the environment, in industrial areas green cover is largely affected by this metal contamination through plant growth retardation. To reduce these toxic effects, some auxin-producing bacterial species living in the rhizosphere have proven to be effective in reducing toxic hexavalent chromium [Cr (VI)] into a less toxic state, i.e., trivalent chromium [Cr (III)]. The present study reveals the potential of chromium-resistant auxin-producing bacteria for bioremediation. For this purpose, plant growth-promoting bacteria that are capable of growing in the presence of chromium were isolated from different industrial areas. The impact of isolated strains on reducing the toxic effects of chromium was analyzed by comparing different growth parameters of inoculated and non-inoculated treatments of Zea mays in the presence and absence of chromium stress. Increments in shoot length of the treated plants was noted up to $23 \%$ due to bacterial inoculation with Halomonas sp. (AST) under chromium stress of $1,000 \mu \mathrm{g} / \mathrm{ml}\left(\mathrm{K}_{2} \mathrm{CrO}_{4}\right)$ as compared to control. Similarly amount of auxin produced in the treated corn plants was improved up to $161 \%$ in treatments with Bacillus cereus (3a) over respective control. These findings suggest that the above mentioned chromium-resistant auxin-producing bacterial isolates can serve as an ecofriendly tool to improve crop production in soils contaminated with chromium.
\end{abstract}

Keywords: indole-3-acetic acid, chromium, PGPR, Zea mays, bioremediation

\section{Introduction}

Industrialization has led to economic development in recent years, resulting in the release of huge quantities

*e-mail: ambreenahmed1@hotmail.com of pollutants from various industries. Industrialization and urbanization culminates in the highest proportions of different contaminants, which have been detected in air, water, and soil. Chromium appears as one of the major heavy metal pollutants posing harmful effects on the environment causing ecological hazards. It is mainly used in a number of industrial processes such as alloy 
formation, chrome plating, metal ceramics, dyes and paints, different molds used for firing of bricks, and in leather tanning. However, it is known to cause health hazards in living organisms, particularly in people working in leather industries who are exposed to chromium and are prone to develop severe allergic reactions as well as other health issues such as stomach disorders and ulcers, respiratory issues, immune system problems, kidney and liver damage, lung damage, and even death in severe cases [1-2].

The rhizosphere is the most active portion of the rootsoil interface where the microbial population participates in different biogeochemical processes [3]. Some bacterial communities are capable of reducing chromium toxicity. These are named as chromium-reducing bacteria (CRB). Among diverse soil microbes, plant growth-promoting bacteria producing plant growth regulators are involved in expediting plant growth in the presence of various metal stresses. Moreover, they have shown excellent results in reducing metal toxicity and promoting plant-growth when used as inoculants. Indole-3-acetic acid (IAA) is an important growth regulator found in plants that promotes growth of the treated plants during development [4]. Among plant-associated bacteria, IAA production is also widespread and is involved in growth promotion of plants by rhizobacterial activity. In fact, growth enhancement is a combination of many factors, but IAA production is a direct mechanism which bacteria adopt for better growth and yield [5-6]. Since IAA plays a crucial role in the growth promotion of plants and some bacterial cultures are able to produce auxin, this criterion can be used as an important tool for the selection of efficient plant growth promoting bacteria (PGPR). Our current work aims at the use of IAA-producing bacteria for bioremediation purposes, as it is imperative to develop economic and environmental friendly methods to treat $\mathrm{Cr}$ (VI) in the industrial wastewater and to reduce the hazardous effects exerted by chromium on human health. In the present work, chromium-resistant bacterial strains with the ability to produce auxin were used for growth stimulation in the absence and presence of chromium.

\section{Experimental Procedures}

\section{Screening and Characterization of Chromium- Resistant Auxin-Producing Bacteria}

Bacterial strains were isolated using contaminated water, plants growing in the vicinity of industries, and soil samples collected from an industrial area in Kasur, Pakistan (Table 1). Minimum inhibitory concentration (MIC) of chromium for the growth of the isolates was determined using $\mathrm{K}_{2} \mathrm{CrO}_{4}$. Chromium-resistant isolates were then screened for auxin production. Three selected (EIV, 3a, EIII) chromium-resistant auxin-producing bacterial strains were characterized morphologically and physiologically. Colony and cell morphology were observed for morphological characterization. For colony morphology, the isolates were grown on L-Agar plates for 24 hours at $37^{\circ} \mathrm{C}$ and the colonies obtained were observed with the naked eye as well as under a stereomicroscope. Colony color, shape, size, margin, elevation, and clarity were recorded [7]. For cell morphology, the bacterial isolates were grown for 24 hours at $37^{\circ} \mathrm{C}$ using L-broth medium. This bacterial culture was then used to prepare bacterial smears that were subjected to gram-staining. After gramstaining, the bacterial cells were observed under the microscope using an oil immersion lens, and cell shape, colour, and cell arrangement were observed [7]. Bacterial culture, which was incubated for 24 hours at $37^{\circ} \mathrm{C}$ using L-broth, was also used to observe motility of the cells under the microscope though the hanging drop method. Bacterial culture grown for 72 hours at $37^{\circ} \mathrm{C}$ using L-broth medium was used for spore staining. The spores were observed under the microscope using an oil immersion lens [7].

For physiological characterization, the impact of various incubation temperatures $\left(25,37\right.$, and $\left.45^{\circ} \mathrm{C}\right)$ on bacterial growth was recorded by taking the optical density of 24-hour grown bacterial cultures in the presence and absence of chromium $\left(\mathrm{K}_{2} \mathrm{CrO}_{4} 500 \mu \mathrm{gml}^{-1}\right)$ using L-broth at $600 \mathrm{~nm}$. The effect of media $\mathrm{pH}$ (i.e., 5, 6, 7, 8, 9) on bacterial growth was monitored for which the bacterial cultures were grown for 24 hours at $37^{\circ} \mathrm{C}$ using L-broth in the presence and absence of chromium $\left(\mathrm{K}_{2} \mathrm{CrO}_{4} 500 \mu \mathrm{gml}^{-1}\right)$, and optical density was monitored at $600 \mathrm{~nm}$. Bacterial isolates were also grown for varying times of incubation $(0,24,48,72$, and 96 hours $)$ at $37^{\circ} \mathrm{C}$ using L-broth in the presence and absence of chromium $\left(\mathrm{K}_{2} \mathrm{CrO}_{4} 500 \mu \mathrm{gml}^{-1}\right)$, and their optical density (O.D.) was recorded at $600 \mathrm{~nm}$. For inoculation of the bacterial cultures to investigate the effect of temperature, $\mathrm{pH}$, and time of incubation, optical density of the bacterial cultures were adjusted to $10^{6}$ to $10^{7} \mathrm{CFU}$ per $\mathrm{ml}$, and these cultures were used for inoculation of the replicates. Three replicates for each treatment were taken. Bacterial isolates were also grown in the presence of various antibiotics discs [Clarithromycin (CLR), Cefobid (CFP), Trimethoprim (SXT), Fortum (CAZ), Rocephin (CRO), Cefazolin (CZ), and Pyopen (PY)], and various metals $(\mathrm{Co}, \mathrm{Mn}, \mathrm{Hg}, \mathrm{Fe}, \mathrm{Cr}$, Co) $\left(500 \mathrm{\mu gml}^{-1}\right)$ and growth of the isolates was recorded.

These isolates were then identified using $16 \mathrm{~S}$ rDNA sequencing and sequences obtained were searched for homology through BLAST and submitted to GenBank for accession numbers. Three isolates (i.e., EIV, 3a, and EIII) were used for the present study along with two already identified bacterial strains, i.e., Halomonas sp. (AST) and Arthrobacter mysorens (AHA) isolated by Ahmed [8].

\section{Plant-Microbe Interaction}

Five chromium-resistant auxin-producing isolates (EIV, 3a, AST, AHA, and EIII) were used to inoculate Zea mays plants with and without the addition of chromium stress. The effect of bacterial cultures with and without chromium stress on the growth of the inoculated plants was observed by comparing various growth parameters with 
Table 1. Isolation of auxin-producing chromium-resistant bacterial strains from contaminated water and soil samples.

\begin{tabular}{|c|c|c|c|c|}
\hline $\begin{array}{l}\text { Sr. } \\
\text { No. }\end{array}$ & Location & Isolated Strains & $\begin{array}{l}\text { Chromium Resistance }\left(\mathrm{K}_{2} \mathrm{CrO}_{4}\right) \\
1,000 \mu \mathrm{g} / \mathrm{ml}\end{array}$ & Auxin Production \\
\hline 1 & \multirow{7}{*}{$\begin{array}{c}\text { Water sample I } \\
\text { (Industrial area, Kasur) }\end{array}$} & $2 \mathrm{ab}$ & - & - \\
\hline 2 & & H1 & - & - \\
\hline 3 & & $3 a$ & +++ & +++ \\
\hline 4 & & $3 b$ & _- & - \\
\hline 5 & & 4aIII & + & + \\
\hline 6 & & $2 \mathrm{aa}$ & - & - \\
\hline 7 & & IC & - & - \\
\hline 8 & \multirow{2}{*}{$\begin{array}{l}\text { Water sample II } \\
\qquad \text { (PU) }\end{array}$} & H2aIII & - & ++ \\
\hline 9 & & $\mathrm{H} 2 \mathrm{aI}$ & - & +++ \\
\hline 10 & $\begin{array}{l}\text { Water sample III } \\
\text { (Secretariat, Lahore) }\end{array}$ & H1aII & - & +++ \\
\hline 11 & $\begin{array}{c}\text { Soil sample I } \\
\text { (Industrial area, Kasur) }\end{array}$ & AR & + & + \\
\hline 12 & \multirow{4}{*}{$\begin{array}{c}\text { Soil sample II } \\
\text { (Industrial area, Kasur) }\end{array}$} & EI & + & ++ \\
\hline 13 & & EII & + & + \\
\hline 14 & & EIII & ++ & +++ \\
\hline 15 & & EIV & ++ & ++ \\
\hline 16 & $\begin{array}{c}\text { Suaeda fruticosa } \\
\text { (Industrial area, Kasur) }\end{array}$ & Ala & + & + \\
\hline 17 & $\begin{array}{l}\text { Amaranthus viridus } \\
\text { (Industrial area, Kasur) }\end{array}$ & BL2 & - & + \\
\hline
\end{tabular}

$(-)$ no growth, $(+)$ slight growth, $(++)$ good growth, $(+++)$ excellent

the non-treated plants. Certified seeds of Zea mays var. desi bharia were procured from Punjab Seed Corporation in Lahore, and were surface sterilized by treating them with a standard solution of $0.1 \% \mathrm{HgCl}_{2}$ for 5 to 6 minutes and washed several times with autoclaved deionized water. These sterilized seeds were treated with bacterial cultures after adjusting the optical density of cultures to $10^{6}$ to $10^{7} \mathrm{CFU} \mathrm{ml}{ }^{-1}$. For control treatment, seeds were treated with autoclaved distilled water for the same period of time.

The inoculated seeds of Zea mays var. desi bharia were uniformly spread on sterilized filter paper in autoclaved petriplates with the help of a sterilized forcep. Ten $\mathrm{ml}$ of chromium salt solution of varying concentrations $(0,100$, $200,400,800$, and $1,000 \mu \mathrm{g} / \mathrm{ml}$ ) was supplied to each respectively labeled autoclaved petri-plate containing sterilized seeds. Petriplates were kept in the dark at $25+2^{\circ} \mathrm{C}$ for three days. After germination, germinated seedlings were transferred to labelled pots, each containing 140 $\mathrm{g}$ sieved soil and chromium stress solution of varying concentrations $(0,100,200,400,800$, and $1,000 \mu \mathrm{g} / \mathrm{ml})$ of chromium salt $\left(\mathrm{K}_{2} \mathrm{CrO}_{4}\right)$ was given to the respective labelled pots. Seven seeds were sown per pot in the laboratory experiment and three replicates were taken for each treatment. The pots were placed in light $(10 \mathrm{~K}$ lux, 16 hours duration) at $25+2^{\circ} \mathrm{C}$. The soil used in the current experiment was natural garden soil. Properties of the soil such as $\mathrm{pH}$, temperature, and electrical conductivity were recorded. For laboratory trial, seedlings were harvested from pots after 25-30 days of growth and growth parameters (i.e., shoot length, root length, number of leaves, and fresh weight) were recorded. For field trials, $7.3 \mathrm{~kg}$ natural garden soil was taken in pots. In the field experiment, five seeds were sown per pot and three replicates were used for each treatment. No fertilizers were added in both the laboratory and field experiments. The plants grown were harvested at maturity. Different growth parameters that were recorded for field trials include shoot length, leaf number of plants, and yield of the plants in terms of number of corn cobs. The biochemical parameters that were checked after field trials include auxin content, pigment content, and protein content, for which leaves of the treated and non-treated plants were taken. In both laboratory and field trials, shoot and root lengths were measured through the software Image J. Auxin, pigment, and protein contents were estimated by following Mahadevan [9], Lichtenthaler and Wellburn [10], and Lowry et al. [11], respectively. 


\section{Statistical Analysis}

The data obtained was statistically analyzed using the SPSS software by applying Duncan's multiple range test.

\section{Results}

\section{Screening and Characterization of Chromium- Resistant Auxin-Producing Bacteria}

Initially 17 bacterial strains $(\mathrm{H} 1,2 \mathrm{ab}, 3 \mathrm{a}, 2 \mathrm{aa}, 3 \mathrm{~b}$, 4aIII, IC, H2aIII, H2aI, H1aII, AR, EI, EII, EIII, ALa, EIV, and BL2) were isolated from contaminated soil, water, and plant samples (Table 1). On the basis of their auxin-production and chromium-resistance ability, three bacterial isolates (EIII, EIV, and 3a) were selected for the current study. Two already isolated, characterized, and identified chromium-resistant auxin-producing bacterial strains - Halomonas sp. (AST) and Arthrobacter mysorens (AHA) by Ahmed [8], were also used for the current study. The selected isolates EIV, 3a, and EIII were characterized morphologically and physiologically. Two isolates, EIII and $3 \mathrm{a}$, produced transparent colonies with entire margins, while colonies of Bacillus sp. (EIV) showed dentate margin and were opaque. The three isolates (i.e., EIV, 3a, and EIII) were gram-positive motile rods and were spore-formers. All five bacterial cultures have shown the highest growth at $37^{\circ} \mathrm{C}$ after 24 hours incubation period in the absence and presence of chromium. However, in the presence of chromium stress $(1,000 \mu \mathrm{g} / \mathrm{ml})$, reduction in growth of all the bacterial strains was observed as compared to isolates grown in medium without chromium after 24 hours incubation. Better growth of the isolates was recorded in medium with neutral $\mathrm{pH}$, but maximum growth was noted with alkaline $\mathrm{pH}$. The isolates were grown in the presence of different antibiotic discs (Cefobid (CFP), Clarithromycin (CLR), Rocephin (CRO), Trimethoprim (SXT), Cefazolin (CZ), Fortum (CAZ), Pyopen (PY)). All the isolates were sensitive to the antibiotics Clarithromycin (CLR) and Trimethoprim (SXT) with varying inhibition zones except EIV and AST (Fig. 1). The bacterial isolates were also grown in the presence of different metals in the growth medium. All five bacterial cultures were found

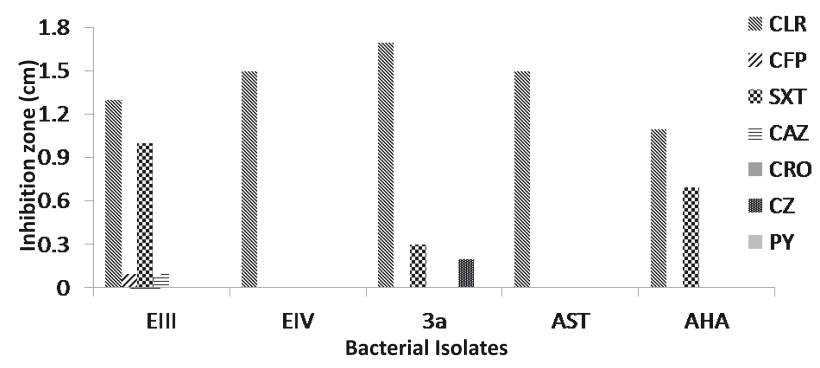

Fig. 1. Antibiotic resistance of the bacterial isolates Clarithromycin (CLR), Cefobid (CFP), Trimethoprim (SXT), Fortum (CAZ), Rocephin (CRO), Cefazolin (CZ), and Pyopen (PY).

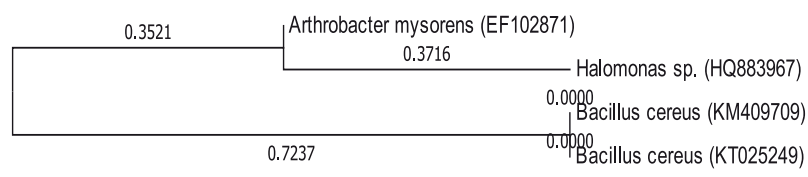

0.1

Fig. 2. Phylogenetic tree showing the evolutionary relationship of the isolates. Bacillus cereus (EIV), Halomonas sp. (AST), Bacillus cereus (3a), and Arthrobacter mysorens (AHA).

to be resistant against $\mathrm{Cu}, \mathrm{Fe}, \mathrm{Mn}$, and $\mathrm{Cr}$, but were sensitive to the presence of $\mathrm{Hg}$. One bacterial strain, i.e., EIII, was sensitive against Co, while the rest of the isolates showed resistance to Co. 16S rDNA sequencing of isolates EIV and 3a was carried out and the sequences obtained were submitted to GenBank. The isolate 3a has shown $98 \%$ similarity to Bacillus cereus with accession number KM409709, while the bacterial isolate EIV has shown 99\% homology with Bacillus cereus and was given accession number KT025249 (Fig. 2).

\section{Plant-Microbe Interaction}

Plant-microbe interaction increases the growth of plants by reducing the toxic effects of chromium in chromium-contaminated sites. In order to study the effect of the bacterial isolates, Bacillus cereus (3a), Halomonas sp. (AST), Bacillus sp. (EIV), Arthrobacter mysorens (AHA), and EIII, to reduce chromium toxicity, Zea mays var. desi baharia was grown in the absence and presence of bacterial inoculum with and without chromium stresses $(0$, $100,200,400,800$, and $1000 \mu \mathrm{g} / \mathrm{ml})$. Temperature, $\mathrm{pH}$, and electrical conductivity of the soil used was recorded to be $29^{\circ} \mathrm{C}, \mathrm{pH} 8$, and $0.71 \mathrm{mS}^{-1}$, respectively. Among the various elements, zinc $(\mathrm{Zn})$, calcium $(\mathrm{Ca})$, and iron $(\mathrm{Fe})$ were found to be present in the soil used. In the laboratory experiment, shoot lengths of the plants inoculated with bacterial strains exhibited growth promotion over control treatment. Increases in shoot and root lengths were observed significantly with the inoculation of Bacillus cereus (3a) showing 19 and 29\% enhancement in shoot and root lengths, respectively (Fig. 3). Increases in chromium stress $\left(\mathrm{K}_{2} \mathrm{CrO}_{4}\right)$ from $100-1,000 \mu \mathrm{g} / \mathrm{ml}$ caused growth retardation in the shoot and root lengths of the plants due to the toxic effects of chromium (Fig. 3).

Bacterial inoculation with the isolate EIII has shown 20 and 34\% increments in shoot lengths under chromium stress of 800 and $1,000 \mu \mathrm{g} / \mathrm{ml}$, respectively, over respective control. Similarly, under chromium stress of $1,000 \mu \mathrm{g} / \mathrm{ml}$, enhancement in root length was observed with Halomonas sp. (AST) up to $23 \%$ over respective control. Bacterial inoculations with all the strains including Bacillus cereus (EIV), Arthrobacter mysorens (AHA), Bacillus sp. (3a), Halomonas sp. (AST), and EIII resulted in increases in the leaf number when compared with the control up to $13,13,13,13$, and $7 \%$, respectively, under laboratory conditions (Fig. 4). Under chromium stress of 


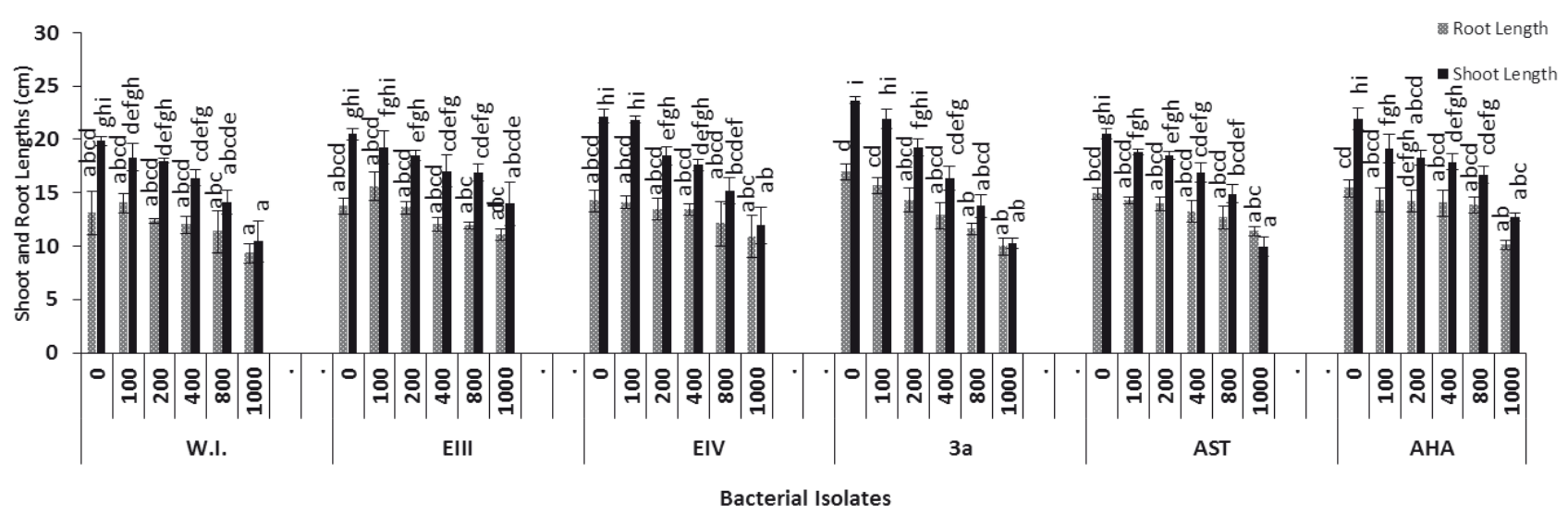

Fig. 3. Effects of bacterial inoculations without chromium stress $\left[\mathrm{K}_{2} \mathrm{CrO}_{4}(0 \mu \mathrm{g} / \mathrm{ml})\right]$ and with chromium stress $\left[\mathrm{K}_{2} \mathrm{CrO}{ }_{4}\right.$ $(100-1,000 \mu \mathrm{g} / \mathrm{ml})$ ] on shoot and root lengths $(\mathrm{cm})$ of Zea mays under laboratory conditions. Data represent the mean of 21 replicates. Different letters indicate significant differences between treatments using Duncan's multiple range test $(\mathrm{P}=0.05)(0=$ without chromium stress; W.I. = without bacterial inoculation; EIII, EIV, 3a, AST, and AHA = bacterial isolates).

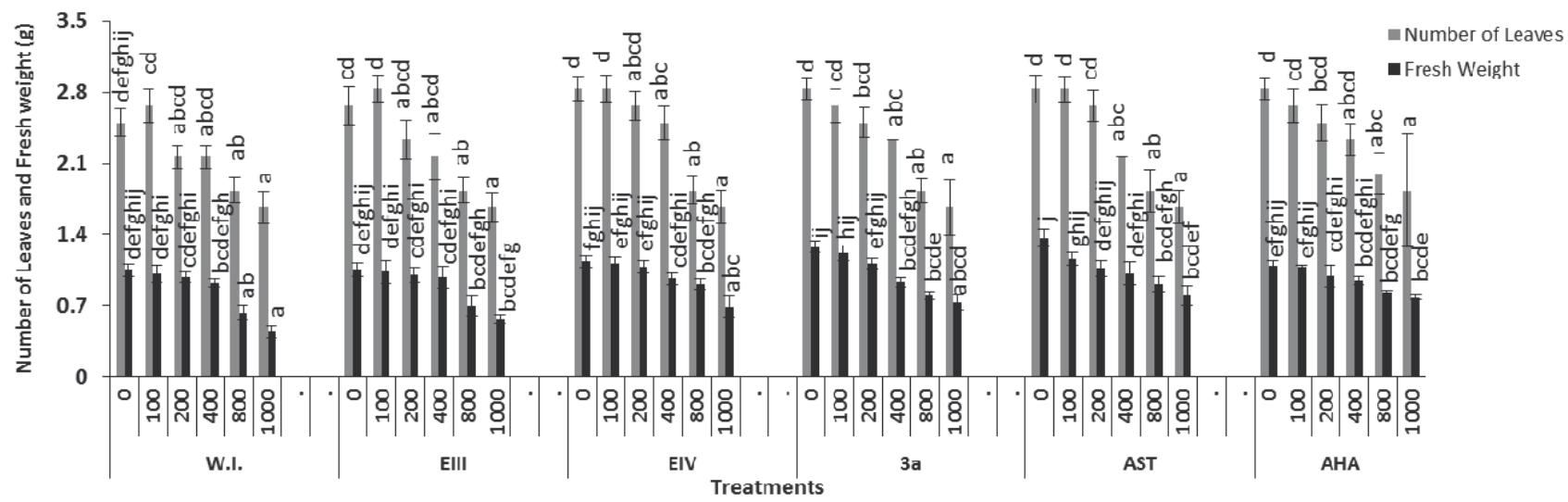

Fig. 4. Effects of bacterial inoculations without chromium stress $\left[\mathrm{K}_{2} \mathrm{CrO}_{4}(0 \mu \mathrm{g} / \mathrm{ml})\right]$ and with chromium stress $\left[\mathrm{K}_{2} \mathrm{CrO}{ }_{4}\right.$ $(100-1,000 \mu \mathrm{g} / \mathrm{ml})]$ on the number of leaves and fresh weight $(\mathrm{g})$ of Zea mays under laboratory conditions. Data represent the mean of 21 replicates. Different letters indicate significant differences between treatments using Duncan's multiple range test $(P=0.05)(0=$ without chromium stress; W.I. = without bacterial inoculation; EIII, EIV, 3a, AST, and AHA = bacterial isolates).

$200 \mu \mathrm{g} / \mathrm{ml}\left(\mathrm{K}_{2} \mathrm{CrO}_{4}\right)$, an increase in the number of leaves was noted with inoculation of Halomonas sp. (AST), i.e., $23 \%$ over respective control treatment (Fig. 4).

Bacterial treatment also improved fresh weight of the inoculated plants. Under chromium stress of 100 and $200 \mu \mathrm{g} / \mathrm{ml}\left(\mathrm{K}_{2} \mathrm{CrO}_{4}\right), 20$ and $15 \%$ increments in fresh weight of the treated plants were observed due to inoculation with Bacillus cereus (3a), respectively. Moreover, 10, 45 , and $78 \%$ increases in fresh weight of the treated plants was recorded due to bacterial inoculation with Halomonas sp. (AST) under chromium stress of 400, 800 , and $1,000 \mu \mathrm{g} / \mathrm{ml}\left(\mathrm{K}_{2} \mathrm{CrO}_{4}\right)$ when compared with the respective control treatment (Fig. 4). In the field experiment, shoot lengths of the plants were improved as a result of bacterial inoculations over non-inoculated control treatments. The highest increase in shoot length of the treated plants was noted with the bacterial isolate Halomonas sp. (AST), exhibiting a 49\% increase in shoot length (Fig. 5). Other isolates Bacillus cereus (EIV), Arthrobacter mysorens (AHA), Bacillus cereus (3a), and
EIII showed 19, 34, 14, and 5\% increases in length of shoots over control treatment without inoculation. Under chromium stress $\left(\mathrm{K}_{2} \mathrm{CrO}_{4}\right)$ ranging from $0-1,000 \mu \mathrm{g} / \mathrm{ml}$, decreases in shoot length were observed showing the hazardous effects of chromium (Fig. 5). In chromiumstressed soil with 800 and $1,000 \mu \mathrm{g} / \mathrm{ml}$ chromium stress, bacterial inoculation with the isolate Halomonas sp. (AST) showed 13 and 23\% improvement in shoot length over respective control. Similarly, treatments with isolates Bacillus cereus (3a) and Arthrobacter mysorens (AHA) caused 33 and $11 \%$ improvement in shoot length over respective control in the presence of chromium stress of $1,000 \mu \mathrm{g} / \mathrm{ml}$ (Fig. 5). Similarly, the number of leaves has been improved in treatment with isolates Bacillus cereus (EIV), Halomonas sp. (AST), Bacllus cereus (3a), Arthrobacter mysorens (AHA), and EIII over control treatment. Treatments with Bacillus cereus (3a) and Arthrobacter mysorens (AHA) have shown higher yield, showing up to 119 and $80 \%$ increases, respectively, over treatment (Fig. 6). 
In the presence of stress of chromium from 100-400 $\mu \mathrm{g} / \mathrm{ml}$, increases in yield were recorded with Bacillus cereus (3a) and Arthrobacter mysorens (AHA), i.e., 100 and $63 \%(100 \mu \mathrm{g} / \mathrm{ml}), 99$ and $82 \%(200 \mu \mathrm{g} / \mathrm{ml})$, and

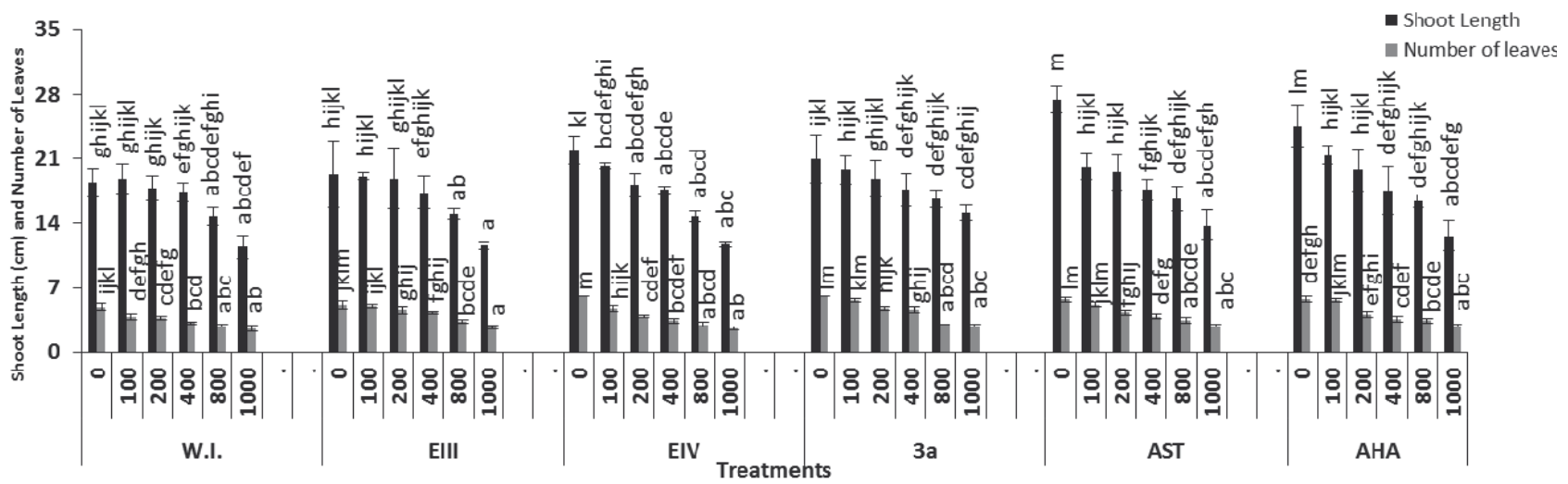

Fig. 5. Effects of bacterial inoculations without chromium stress $\left[\mathrm{K}_{2} \mathrm{CrO}_{4}(0 \mu \mathrm{g} / \mathrm{ml})\right]$ and with chromium stress $\left[\mathrm{K}_{2} \mathrm{CrO}{ }_{4}\right.$ $(100-1,000 \mu \mathrm{g} / \mathrm{ml})]$ on shoot length $(\mathrm{cm})$ and number of leaves of Zea mays under field conditions. Data represent the mean of 15 replicates. Different letters indicate significant differences between treatments using Duncan's multiple range test $(\mathrm{P}=0.05)$ $(0=$ without chromium stress; W.I. = without bacterial inoculation; EIII, EIV, 3a, AST, and AHA = bacterial isolates).

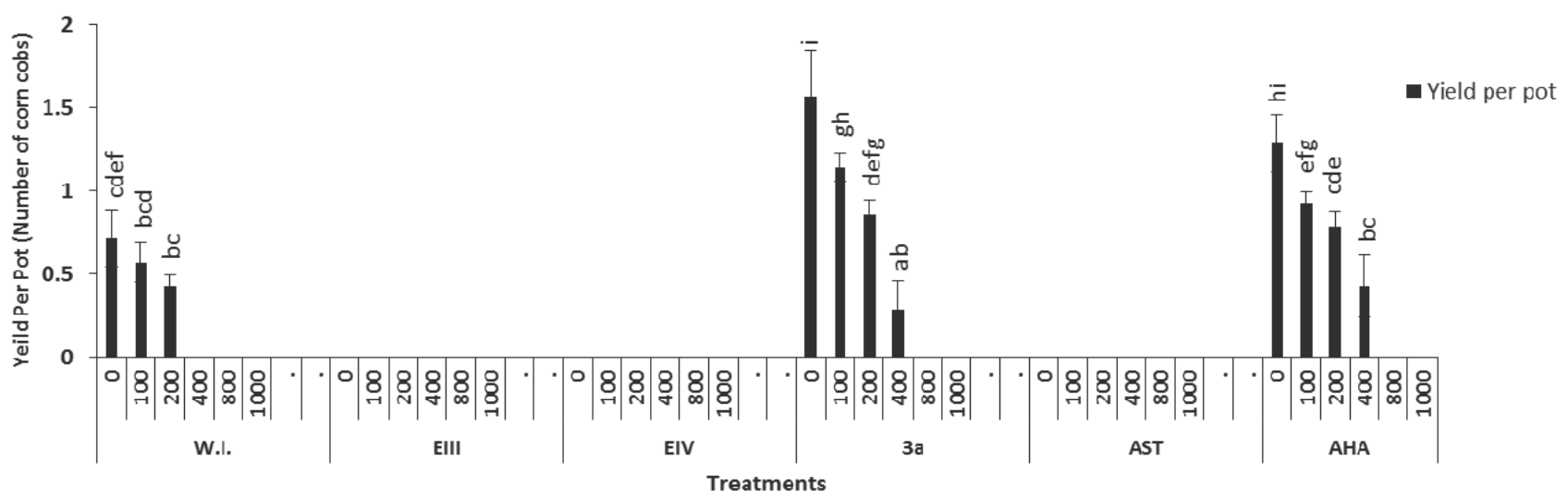

Fig. 6. Effects of bacterial inoculations without chromium stress $\left[\mathrm{K}_{2} \mathrm{CrO}_{4}(0 \mu \mathrm{g} / \mathrm{ml})\right]$ and with chromium stress $\left[\mathrm{K}_{2} \mathrm{CrO}{ }_{4}\right.$ $(100-1,000 \mu \mathrm{g} / \mathrm{ml})]$ on yield of Zea mays under field conditions. Data represent the mean of 15 replicates. Different letters indicate significant differences between treatments using Duncan's multiple range test $(\mathrm{P}=0.05)(0=$ without chromium stress; W.I. $=$ without bacterial inoculation; EIII, EIV, 3a, AST, and AHA = bacterial isolates).

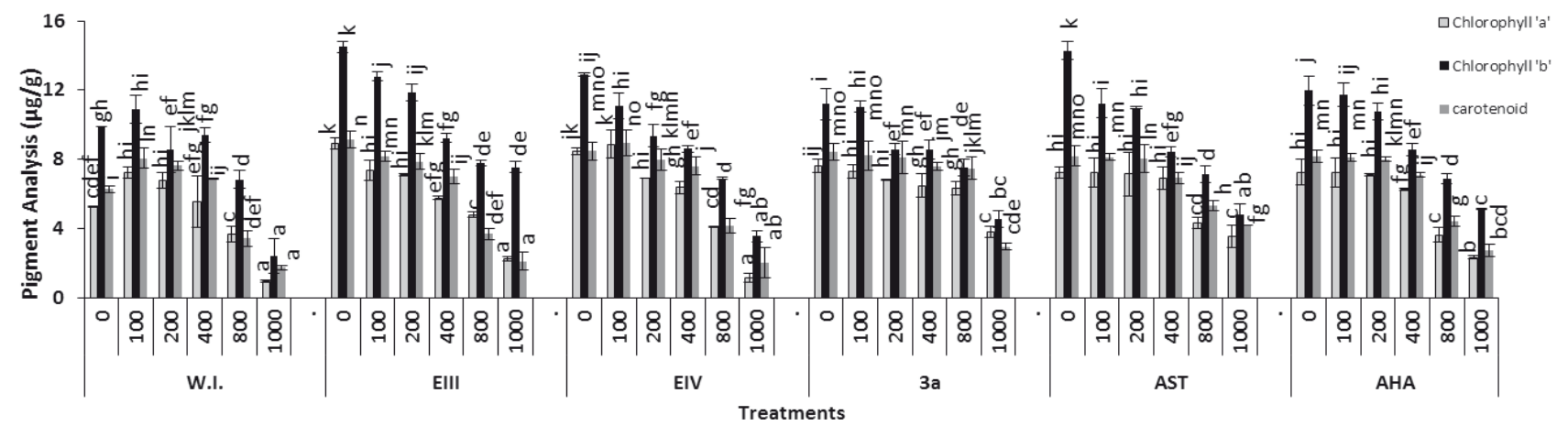

Fig. 7. Effects of bacterial inoculations without chromium stress $\left[\mathrm{K}_{2} \mathrm{CrO}_{4}(0 \mu \mathrm{g} / \mathrm{ml})\right]$ and with chromium stress $\left[\mathrm{K}_{2} \mathrm{CrO}{ }_{4}\right.$ $(100-1000 \mu \mathrm{g} / \mathrm{ml})]$ on chlorophyll 'a,' chlorophyll 'b,' and carotenoid contents $(\mu \mathrm{g} / \mathrm{g})$ of Zea mays. Data represent the mean of $15^{4}$ replicates. Different letters indicate significant differences between treatments using Duncan's multiple range test $(P=0.05)(0=$ without chromium stress; W.I. = without bacterial inoculation; EIII, EIV, 3a, AST, and AHA = bacterial isolates). 
28 and $42 \%(400 \mu \mathrm{g} / \mathrm{ml})$, respectively, over respective control (Fig. 6). Some biochemical parameters were also studied and it was observed that chlorophyll 'a' content of treated plants was improved by bacterial inoculation with the isolates Bacillus cereus (EIV), Halomonas sp. (AST), Bacillus cereus (3a), Arthrobacter mysorens (AHA), and EIII in comparison to the control treatment, i.e., up to $60,40,54,46$, and $78 \%$, respectively, in the absence of chromium (Fig. 7).

The highest increase in the amount of chlorophyll ' $b$ ' was noted with Halomonas sp. (AST) treatment, which showed $41 \%$ increment in the amount of chlorophyll ' $b$ ' in the absence of chromium (Fig. 7). Increases in the stress of chromium $\left(\mathrm{K}_{2} \mathrm{CrO}_{4}\right)$, such as $100-1,000 \mu \mathrm{g} / \mathrm{ml}$, caused decreases in chlorophyll ' $\mathrm{b}$ ' content showing the toxicity of chromium, which adversely affected chlorophyll 'b,' however, significant increases in chlorophyll ' $b$ ' content were recorded as a result of bacterial inoculation with isolate EIII in the presence of chromium stresses, i.e., 100, $200,400,800$, and $1,000 \mu \mathrm{g} / \mathrm{ml}$ with $17,39,10,14$, and $212 \%$ respective increases as compared to control.

Bacterial inoculation with Bacillus cereus (EIV), Halomonas sp. (AST), Bacillus cereus (3a), Arthrobacter mysorens (AHA), and EIII resulted in significant increases in carotenoid content of the plants up to 35 , $31,34,30$, and $45 \%$, respectively, over non-inoculated plants. Under chromium stress of 100, 200, 400, 800, and $1,000 \mu \mathrm{g} / \mathrm{ml}$, treatment of the plants with bacterial isolate Bacillus cereus (3a) has shown 2, 6, 10, 118, and $69 \%$ significant increases, respectively, in carotenoid content when compared with the non-treated plants (Fig. 7). Increases in chromium concentration from 100, 200, 400,800 , and $1,000 \mu \mathrm{g} / \mathrm{ml}$ resulted in a reduction of auxin content of treated plants over control. Without chromium stress, treatment with the bacterial strains Bacillus cereus (EIV), Halomonas sp. (AST), Bacillus cereus (3a), Arthrobacter mysorens (AHA), and EIII have shown significant increments up to $56,34,48,35$, and $161 \%$ in auxin content, respectively, with respect to control (Fig. 8).
The application of isolates on Zea mays elevated the protein content of the treated plants. Significant enhancement in protein content was recorded with bacterial strain Bacillus cereus (3a) showing a 306\% increase over control (Fig. 8). Increase in the concentration of chromium $\left(\mathrm{K}_{2} \mathrm{CrO}_{4}\right)$ from $100-1,000 \mu \mathrm{g} / \mathrm{ml}$ caused a reduction in protein content of inoculated plants. The bacterial isolate Bacillus cereus (3a) significantly increased protein content as compared to non-treated control treatment under chromium stress (0$1,000 \mu \mathrm{g} / \mathrm{ml}$; Fig. 8).

\section{Discussion}

For effective microbe-assisted bioremediation, it is important to characterize and identify metal-resistant bacteria having plant growth-promoting characteristics that may facilitate plant growth and may reduce the toxic impact of metal stress on plant development. It has been observed in recent years that inoculation of heavy metalresistant plant growth-promoting bacteria can improve plant growth under artificially metal-contaminated soils due to their microbial activities in the rhizosphere. In the current work, the effect of bacterial isolates Bacillus cereus (3a), Halomonas sp. (AST), Bacillus cereus (EIV), Arthrobacter mysorens (AHA), and EIII on growth improvement of Zea mays was studied with and without chromium stress. In the laboratory experiment, significant improvement in shoot length was recorded in treatments with Bacillus cereus (3a), i.e., 19\% as compared to non-inoculated control treatment without chromium stress (Fig. 3). Plant growth-promoting bacteria probably induce the development of roots by modulating plant endogenous mechanisms that regulate root growth. Improvements in plant root development resulted in enhanced nutrient uptake, thereby also causing an increase in shoot length of the treated plants.

In chromium-stressed soils ranging from 100-1,000 $\mu \mathrm{g} / \mathrm{ml}$, decreases in shoot length were recorded due to

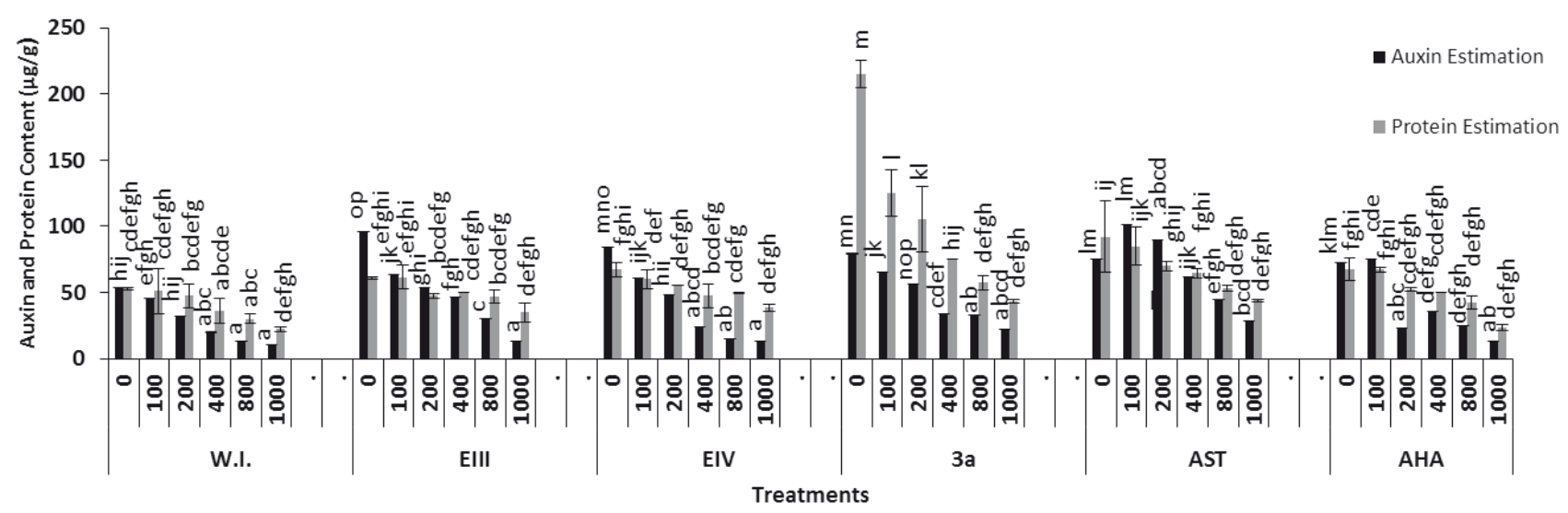

Fig. 8. Effects of bacterial inoculations without chromium stress $\left[\mathrm{K}_{2} \mathrm{CrO}_{4}(0 \mu \mathrm{g} / \mathrm{ml})\right]$ and with chromium stress $\left[\mathrm{K}_{2} \mathrm{CrO}_{4}\right.$ $(100-1,000 \mu \mathrm{g} / \mathrm{ml})]$ on auxin and protein content $(\mu \mathrm{g} / \mathrm{g})$ of Zea mays. Data represent the mean of 15 replicates. Different letters indicate significant differences between treatments using Duncan's multiple range test $(\mathrm{P}=0.05)(0=$ without chromium stress; W.I. $=$ without bacterial inoculation; EIII, EIV, 3a, AST, and AHA = bacterial isolates). 
chromium toxicity, but bacterial inoculations have shown significant improvement in the shoot and root lengths as compared to control at high chromium stresses, for instance the bacterial strains Arthrobacter mysorens (AHA) and EIII, which caused significant increases in shoot lengths up to 22 and $34 \%$, respectively, over control (Fig. 4). In the field experiment, significant improvement of 34 and $49 \%$ in shoot length was recorded as a result of inoculation with Arthrobacter mysorens (AHA) and Halomonas sp. (AST) over control in the absence of chromium stress (Fig. 5). Under chromium stress, i.e., $1,000 \mu \mathrm{g} / \mathrm{ml}$, Bacillus cereus (3a) caused shoot enhancement up to $33 \%$ compared to control. Reactive oxygen species (ROS) potentially enhance differentiation by stopping the cellular processes of the cell cycle and by modifying cell walls of the plants to allow cell expansion. Thus, plant growth-promoting rhizobacteria may change ROS balance within the roots, which result in alterations in growth and developmental changes [12]. Plant growthpromoting bacteria with $\mathrm{Cr}(\mathrm{VI})$ reducing-potential have contributed not only to reducing chromium toxicity but also to enhancing plant biomass in chromium-stressed soils. Under field conditions, significant enhancement in the number of leaves was studied. Bacterial isolates $B a$ cillus cereus (3a), Arthrobacter mysorens (AHA), and EIII promoted growth with a significant increase in leaf number without the addition of chromium stress (Fig. 5). In chromium-stressed soils, the reduction in leaf number indicates that these growth traits can serve as suitable bio-indicators against heavy metal pollution and in the selection of resistant species. Increases in fresh weight (i.e., 30 and $22 \%$ ) were recorded in treatment with bacterial strains Halomonas sp. (AST) and Bacillus cereus (3a), respectively.

Many physiological as well as biochemical processes are severely affected due to the toxic nature of heavy metal pollution and as a result, yield and productivity of the corn cobs are equally affected. Bacterial inoculations caused increments in corn yield. In a chromium-free environment, Arthrobacter mysorens (AHA) resulted in 33\% improvement in the yield (Fig. 6). At chromium stresses of 800 and $1,000 \mu \mathrm{g} / \mathrm{ml}$, the toxicity of chromium was very high - restricting the growth of the plants as well as the number of corn cobs produced in experimental as well as control treatments. Ravari and Heidarzadeh [13] have also observed enhancements in yields of wheat plants treated with Bacillus sp. Other scientists have also noted augmentation in the growth of Cucumis sativus by inoculation with bacteria having growth stimulation potential [14]. The role of such beneficial bacteria in growth proliferation has been reported by other scientists and results show that various root exudates having physical and chemical properties are involved in such growth enhancements [15]. In the present study, corn plants inoculated with growth-promoting bacteria have shown better adaptation while growing in chromium-stressed soils, which may be due to the activity of these microscopic entities that cause changes in plant metabolic pathways, e.g., enhanced proliferation in roots resulting in improved nutrient up- take and increased bacterial siderophore production, etc., in which case they become more tolerant to chromium stress.

The photosynthetic pigments of treated plants were also analysed to evaluate the impact of bacterial inoculations on plant growth. The photosynthetic mechanism is highly affected due to metal toxicity, which may induce biochemical changes, i.e., closure of stomata and intercellular spaces. These changes are induced due to alterations in chloroplast structure [16]. Due to physiological changes in plant cells, i.e., $\mathrm{CO}_{2}$ fixation, electron transport, photophosphorylation, and enzyme activities, etc., the amount of photosynthetic pigments is decreased in chromium-stressed soils. However, chromium-tolerant plant growth-promoting bacteria seem to reduce the toxic effect of Cr-contamination resulting in improvement of chlorophyll 'a,' chlorophyll 'b,' and carotenoid content of the treated plants. Without chromium stress the bacterial strains Bacillus cereus (3a) and EIII caused significant enhancement in the amount of chlorophyll ' $a$ ' with 60 and $78 \%$ increases, respectively, over control. In chromium-stressed soils ranging from 100, 200, 400, 800, and $1,000 \mu \mathrm{g} / \mathrm{ml}$, significant improvement in chlorophyll ' $\mathrm{a}$ ' was observed in treatment with Bacillus cereus (EIV) over control (Fig. 7). Chlorophyll 'b' was also significantly increased up to $41 \%$ as a result of treatment with Halomonas sp. and Bacillus cereus (3a), respectively, over control without chromium stress. In the presence of chromium stress of $1,000 \mu \mathrm{g} / \mathrm{ml}$, EIII significantly improved chlorophyll ' $b$ ' content up to $212 \%$ as compared to respective control. Carotenoid content was also enhanced by bacterial inoculations up to 34 and $45 \%$ increases with bacterial strains Bacillus cereus (3a) and EIII, respectively, in comparison to non-inoculated treatment (Fig. 7). Bacterial isolates Bacillus cereus (3a) and EIII showed significant enhancement in the auxin content over respective control without the addition of chromium stress with 48 and 161\% improvement, respectively.

The amount of auxin produced by bacteria having growth stimulation potential has been shown to correlate with the ability to improve plant growth for several bacterial species and isolates from the rhizosphere. The cellular metabolic pathways of such bacterial species regarding enhancement in root systems are generally accompanied by induced changes in plant endogenous responses. Since several bacteria having growth stimulation potential have been shown to produce these growth hormones, it is interesting to suggest that these changes may be induced by these hormones directly. This was probably due to the inhibition of ethylene production in the roots by the activity of ACC deaminase that utilizes the $\mathrm{NH}_{3}$ evolved from ACC as a source of nitrogen and thereby decreased ACC in the plants [17]. In the presence of chromium stress of $1,000 \mu \mathrm{g} / \mathrm{ml}$, treatments with Halomonas sp. (AST) showed maximum increase in auxin content of the treated plants, i.e., $182 \%$ as compared to the respective control treatment (Fig. 8). Bacterial inoculations also caused significant enhancement in protein content, i.e., Halomonas sp. (AST) and Bacillus cereus (3a) exhibited 
74 and 306\% increments, respectively, with control in the absence and presence of chromium (Fig. 8). Other workers have also reported improvements in biochemical parameters of treated plants such as chlorophyll content and auxin content, etc. [18]. Growth improvement in inoculated corn plants with reference to various growth and biochemical parameters suggested that these chromiumresistant auxin-producing isolates can be used as natural tools for bioremediation and plant growth improvement in chromium-contaminated areas.

\section{Conclusion}

The results of this study have shown that bioremediation potential of the selected bacterial cultures is a promising approach. These bacterial isolates were resistant against chromium and have the ability to produce auxin. This approach has been helpful in reducing the hazardous effects of chromium, thereby enhancing plant growth by affecting different growth and biochemical parameters of the inoculated treatments when compared with the noninoculated treatments. Overall significant improvements were obtained in various parameters by treatment with the isolates Bacillus cereus (3a) and Halomonas sp. (AST) in reducing chromium toxicity over control. Thus these isolates can be utilized effectively for bioremediation of contaminated soils as a cost-effective natural approach for lowering chromium toxicity in plants in comparison with synthetic methods that are expensive and hazardous.

\section{Acknowledgements}

University of the Punjab, Lahore, Pakistan is greatly acknowledged for its financial support.

\section{References}

1. ISLAM F., YASMEEN T., ALI Q., MUBIN M., ALI S., ARIF M.S., HUSSAIN S., RIAZ M., ABBAS F. Copperresistant bacteria reduces oxidative stress and uptake of copper in lentil plants: potential for bacterial bioremediation. Environ. Sci. Pollut. R. 23, 220, 2016.

2. MOHAMMAD M.M. Plant Growth Promoting Rhizobacteria, J. Soil Sci.Plant Nutr. 37 (14), 2227, 2014.

3. GHANI A., KHAN I., UMER S., AHMED I., MUSTAFA I., MOHAMMAD N. Response of Wheat (Triticum aestivum) to Exogenously Applied Chromium: Effect on Growth, Chlorophyll and Mineral Composition. J. Environ. Anal. Toxicol. 5 (3), doi:10.4172/2161-0525.1000273, 2015.

4. NASEEM S., YASIN M., AHMED A., FAISAL M. Chromium accumulation and toxicity in Corn (Zea mays L.) seedlings, Pol. J Environ. Stud. 24 (2), 899, 2015.

5. STANOJEVIĆ D., ĐORĐEVIĆ S., ŠIMIĆ B., RADAN Z. Wheat seeds (Triticum aestivum L.) growth promotion by bacterial auxin, in vitro. Agoecology, Organic Agriculture and Environment Protection, 49. hrvatski i 9. međunarodni simpozij agronoma, Dubrovnik, Hrvatska, 2014.

6. AHMED A., HASNAIN S. Auxins as one of the factors of plant growth improvement by plant growth promoting rhizobacteria. Pol J Microbiol. 63 (3), 261, 2014.

7. CAPPUCCINO J.G., SHERMAN N. In: Microbiology: a laboratory manual. $7^{\text {th }}$ edition. Pearson Education, Inc. 2005.

8. AHMED A. In: Efficacy of bacterial hormone in plant growth promotion, 2011.

9. MAHADEVAN A. In: Growth regulators, Microorganisms and diseased plants. Oxford and IBH Publishing Company, India, 31, 1984.

10. LICHTENTHALER H.K., WELLBURNA.R. Determination of total carotenoids and chlorophyll a and b of leaf extracts in different solvents. Biochem. Soc. Trans. 11 (5), 591, 1983.

11. LOWRY O.H., RESEBROUGH N.J., FARR A.L. Protein measurement with the folin-phenol reagent. J. Biol. Chem. 193, 265, 1951.

12. VAFADARA F., AMOOAGHAIEA R., OTROSHYB M., Effects of plant-growth-promoting rhizobacteria and arbuscular mycorrhizal fungus on plant growth, stevioside, NPK and chlorophyll content of Stevia rebaudiana. J. Plant Interact. 2 (6), 1, doi: org/10.1080/17429145.2013.77903, 2013.

13. RAVARI S.B., HEIDARZADEH N. Isolation and characterization of rhizosphere auxin producing Bacilli and evaluation of their potency on wheat growth improvement. Arch. Agron. Soil Sci. 60 (7), 895, 2014.

14. STEFAN M., MUNTEANU N., STOLERU V., MIHASAN M. Effects of inoculation with plant growth promoting rhizobacteria on photosynthesis, antioxidant status and yield of runner bean. ROM. BIOTECH. 18 (2), 8132, 2013.

15. KHAN M.Y., ASGHAR H.N., JAMSHAID M.U., AKHTAR M.J., ZAHIR Z.A. Effect of microbial inoculation on Wheat Growth and Phyto-stabilization of Chromium contaminated soil. Pakistan J. Bot, 45 (1), 27, 2013.

16. TAILOR A.J., JOSHI B.H. Harnessing Plant Growth Promoting Rhizobacteria beyond Nature: A Review, J. Plant Nutr. 37 (9), 1534, 2014.

17. GLICKB.R. Using soil bacteria to facilitatephytoremediation. Biotechnol. Adv, 28, 367, 2010.

18. KUMAR M.N., PAUL E., VERSLUES P.E. Stress physiology functions of the Arabidopsis histidine kinase cytokinin receptors, Physiol. Plantarum. ISSN 0031-9317, 2014. 